\title{
MASA JABATAN KEPALA DESA DALAM PERSPEKTIF KONSTITUSI
}

\author{
Riza Multazam Luthfy \\ Fakultas Syariah dan Hukum, Universitas Islam Negeri Sunan Ampel, Surabaya \\ rizamultazamluthfy@gmail.com
}

\begin{abstract}
The magnitude of the power of the village head since the New Order era was responded to by the issuance of legislation concerning the village after the reformation by limiting his tenure. This paper analyzes the comparison of restrictions on the power of the village head through his tenure in Law No. 22/1999, Law No. 32/2004, and Law No. 6/2014. The author concludes that based on the law approach, the limitation has deteriorated especially in Law No. 6/2014. As for based on the constitutionalism approach, the norm regarding the permissibility of someone serving as the village head for three periods (18 years) in Law No. 6/2014 contradicts the direction of legal politics in the 1945 Constitution and is considered unconstitutional.
\end{abstract}

Keywords: Tenure; Village Head; Constitutionalism

\begin{abstract}
Abstrak
Besarnya kekuasaan kepala desa sejak masa Orde Baru direspon dengan terbitnya peraturan perundang-undangan tentang desa setelah reformasi dengan membatasi masa jabatannya. Tulisan ini menganalisis perbandingan pembatasan kekuasaan kepala desa melalui masa jabatannya pada UU No. 22/1999, UU No. 32/2004, dan UU No. 6/2014. Penulis menyimpulkan bahwa berdasarkan pendekatan undang-undang, pembatasan tersebut mengalami kemerosotan terutama pada UU No. 6/2014. Adapun berdasarkan pendekatan konstitusionalisme, norma tentang diperkenankannya seseorang menjabat sebagai kepala desa selama tiga periode (18 tahun) dalam UU No. 6/2014 bertolak belakang dengan arah politik hukum dalam UUD NRI 1945 sekaligus dinilai inkonstitusional.
\end{abstract}

Kata Kunci: Masa Jabatan; Kepala Desa; Konstitusi

\section{A. Pendahuluan}

Setelah tumbangnya penguasa Orde Baru pada tahun 1998, isu perubahan menggema ke berbagai penjuru. Munculnya isu ini ternyata cukup berimbas pada berubahnya sejumlah produk legislasi yang berhubungan dengan desa. Tekanan dari berbagai kalangan menyebabkan munculnya kecenderungan bahwa peraturan perundangundangan tentang desa yang diterbitkan pasca-reformasi ingin mengurangi kekuasaan kepala desa yang begitu besar. Pengarusutamaan wacana desentralisasi dan demokratisasi pada waktu itu membuat peraturan perundang-undangan bernuansa populis.
Sebagaimana diketahui, saat Orde Baru berkuasa, dominasi kepala desa di level akar rumput (grassroots) sangat kuat. Hal ini terutama merupakan imbas diterbitkannya Undang-Undang Nomor 5 Tahun 1979 tentang Pemerintahan Desa. Aturan politik desa pada masa Orde Baru mengkondisikan bahwa pembentukan sistem politik bersifat tertutup dan monopolistik. Kepala desa adalah penguasa tunggal di desa yang menjadi kepanjangan tangan pemerintah pusat. Tidak ada lembaga desa lainnya yang mampu menjalankan fungsi check and balances. Otonomi desa dihilangkan, adapun campur tangan negara cukup terasa (Permana, 2010). 
\begin{tabular}{llr}
\multicolumn{1}{c}{ Intervensi } & \multicolumn{1}{c}{ negara } & terhadap \\
pemerintahan & di bawahnya & dilakukan \\
dengan & penyeragaman & struktur \\
pemerintahan & desa yang salah & satunya
\end{tabular} mengakibatkan terjadinya proses sentralisasi kekuasaan, melalui penempatan kepala desa selaku penguasa tunggal di level lokal (Fahmi, 2002). Hal ini diperparah dengan kenyataan bahwa seluruh anggota lembaga legislatif desa (LMD) ditunjuk oleh kepala desa, bukan oleh masyarakat, di mana kemampuan mereka masih sangat diragukan. Akhirnya timbul kesangsian apakah aspirasi atau pendapat masyarakat bisa disalurkan untuk dimasukkan ke dalam Keputusan Desa.

Setelah rezim pemerintahan Orde Baru lengser, besarnya kekuasaan kepala desa antara lain dipangkas melalui peraturan perundang-undangan pasca reformasi, yaitu UU No. 22/1999, UU No. 32/2004, dan UU No. 6/2014. Upaya memangkas kekuasaan kepala desa yang dimaksud antara lain dengan memberikan penegasan terhadap batasan masa jabatan kepala desa. Hal ini bukan berarti bahwa peraturan perundangundangan sebelumnya tidak mengatur masa jabatan kepala desa. Ketentuan mengenai berapa lama seseorang dapat menjabat kepala desa sesungguhnya telah diatur dalam produk legislasi. Akan tetapi, dalam praktiknya, ketetapan ini sering dilanggar.

Masa jabatan kepala desa dalam UU No. 22/1999, UU No. 32/2004, dan UU No. 6/2014 menjadi obyek kajian penulis. Dengan pertama-tama menggunakan pendekatan undang-undang, tulisan ini bermaksud membandingkan pembatasan kekuasaan melalui masa jabatan kepala desa pada ketiga undang-undang tersebut. Setelah mengetahui undang-undang mana yang dinilai paling merosot dalam usaha membatasi kekuasaan kepala desa melalui masa jabatannya, penulis selanjutnya menggunakan pendekataan teori. Bagi penulis, suatu teori berfungsi menggali lebih jauh merosotnya pembatasan kekuasaan melalui masa jabatan kepala desa dalam peraturan perundang-undangan. Dalam konteks inilah, konstitusi dipakai oleh penulis sebagai pisau analisis yang dianggap paling sesuai dan relevan. Hal ini juga merupakan state of the art yang merupakan kebaharuan tulisan ini dibandingkan dengan tulisan-tulisan sebelumnya.

Berdasarkan paparan di atas, tulisan ini bermaksud mengkaji dan menganalisis dua hal. Pertama, bagaimana perbandingan pembatasan kekuasaan melalui masa jabatan kepala desa pada UU No. 22/1999, UU No. 32/2004, dan UU No. 6/2014? Kedua, bagaimana pembatasan kekuasaan melalui masa jabatan kepala desa dalam peraturan perundang-undangan menurut tinjauan konstitusi?

\section{B. Pembahasan}

1. Perbandingan Pembatasan Kekuasaan melalui Masa Jabatan Kepala Desa pada UU No. 22/1999, UU No. 32/2004, dan UU No. 6/2014

Dengan terbitnya Undang-Undang No. 22/1999 tentang Pemerintahan Daerah, rezim reformasi menentukan masa jabatan kepala desa selama 8 (delapan) tahun. Produk hukum pengganti Undang-Undang Nomor 5 Tahun 1974 tentang Pokok-Pokok Pemerintahan di Daerah dan UndangUndang Nomor 5 Tahun 1979 tentang Pemerintahan Desa tersebut bermaksud memosisikan kembali desa selaku selfgoverning community. Pada prinsipnya, merujuk Gregorius Sahdan, self-governing community adalah komunitas lokal beyond the state yang mampu mengelola diri sendiri menggunakan pranata lokal (Sahdan, 2005).

Para ahli menganggap keluarnya Undang-Undang No. 22/1999 menghadirkan nuansa baru bagi pemerintahan daerah dan pemerintahan desa. Karena melimpahkan kewenangan yang sangat luas kepada daerah untuk mengembangkan potensinya, sejumlah pihak menyebut undang-undang ini sangat demokratis, bahkan liberal. Jika dibandingkan dengan UU No. 5 Tahun 1974, banyak kemajuan di dalamnya. Menanggapi besarnya kewenangan tersebut, sebuah media massa bahkan menyebut adanya "revolusi" pemerintahan daerah (Romli, 2007). 
Selain menjadi sarana menguatkan otonomi desa, undang-undang ini juga berusaha melemahkan kekuasaan dan patronase kepala desa. Sebagaimana diketahui, rezim Orde Baru mengikat pemerintah desa melalui kepala desa. Kecenderungan tersebut bisa ditinjau dari posisi ganda kepala desa, baik sebagai kepala lembaga eksekutif desa (LKMD) maupun kepala lembaga legislatif desa (LMD). Agar pemerintah desa melaksanakan program secara penuh, rakyat menerima instruksi melalui kepala desa. Sebagaimana bupati dan gubernur, pemerintah pusat memposisikan kepala desa selaku penguasa tunggal di level desa (Juliantara, 2000).

Kekuasaan kepala desa pada masa Orde Baru begitu besar dan rentan disalahgunakan. Dengan kewenangan yang luar biasa, para kepala desa tidak memosisikan diri sebagai pengayom masyarakat, melainkan justru meneguhkan posisinya baik di hadapan supradesa maupun warganya. Apalagi, mengutip Dedi Supriadi Adhuri, sistem politik authoritarian yang dikembangkan oleh rezim Orde Baru tidak memungkinkan kepala desa menjadi penyampai aspirasi rakyat (Adhuri, 2002).

Sebagian di antara mereka juga terbukti memperkaya diri dengan aset-aset desa. Berbagai fasilitas dan sarana publik yang semestinya dinikmati oleh rakyat malah dikuasai olehnya demi pemenuhan hasrat pribadi. Guna memperkecil kekuasaan kepala desa inilah, masa jabatannya diturunkan dari 8 tahun menjadi 5 tahun. Langkah ini diharapkan mampu mengubah perilaku kepala desa yang sewenang-wenang serta meminimalisir feodalisme yang tumbuh dalam dirinya.

Menurut catatan historis, bakat feodalisme pemerintah desa merupakan produk kolonial yang cenderung lebih berorientasi pada kepentingan majikan ketimbang kepentingan masyarakat. Kondisi demikian seringkali menjebak pemerintah desa lupa diri sehingga memunculkan oligarki, nepotisme, serta otoritarianisme pemerintahan desa (Mulyono, 2014). Atas dasar itulah, jangka waktu 5 tahun dianggap ideal bagi seorang kepala desa dalam menunaikan tugasnya sebagai pemerintah desa. Terlalu lamanya seseorang duduk selaku kepala desa bisa membuatnya "lupa diri" dengan menyalahgunakan posisi dan jabatan.

Pemangkasan kekuasaan kepala desa sebenarnya juga bisa ditinjau dari adanya pergeseran dari dominasi eksekutif (executife heavy) ke dominasi legislatif (legislative heavy). Ketika rezim Orde Baru runtuh tergantikan oleh orde reformasi, kekuasaan kepala desa dipreteli dengan cara memisahkan lembaga eksekutif dengan lembaga legislatif. Keberadaan BPD yang dipercaya memegang kuasa legislatif mampu membawa pergeseran kekuasaan yang begitu mencolok. Penerbitan UU No. 22/1999 menjadi momentum yang tepat dalam rangka menguatkan posisi lembaga perwakilan di tingkat lokal, sehingga mempunyai daya tawar politik yang tinggi. Heru Cahyono mensinyalir bahwa lahirnya Badan Perwakilan Desa (BPD) selaku lembaga kontrol menjadikan struktur desa tidak lagi didominasi oleh kepala desa (Cahyono, 2005).

Adapun Hans Antlov menyimpulkan bahwa dengan keluarnya UU No. 22/1999, kepala desa setidaknya dituntut melewati tiga 'lapis pemeriksaan'. Hal ini ditempuh dalam rangka meminimalisir kekuasaannya. Pertama, kepala desa dipilih melalui pemilihan 5 (lima) tahun sekali. Kedua, kepala desa menyampaikan laporan pertanggungjawaban kepada warga melalui Badan Perwakilan Desa (BPD). Ketiga, setiap tahun kepala desa juga bertanggungjawab kepada camat (Antlov, 2003).

Pengurangan masa jabatan merupakan sebagian cara pemerintah dan anggota legislatif memangkas patronase kepala desa. Jika pada undang-undang sebelumnya kepala desa menjabat selama 8 tahun (boleh dipilih kembali 1 kali masa jabatan selanjutnya), maka UU No. 22/1999 menetapkan bahwa masa jabatan kepala 
desa adalah 5 tahun (boleh dipilih kembali 1 kali masa jabatan selanjutnya). Ketetapan demikian bertujuan supaya kepala desa tidak kembali menjadi 'raja kecil' di level desa. Panjangnya masa jabatan pemimpin lokal tersebut cukup rentan diselewengkan. Era pemerintahan Orde Baru, dengan coraknya yang sentralistis dan otoriter, telah memberikan keleluasaan kepala desa untuk mengondisikan warganya. Bagaimanapun, kepala desa menjadi medium terlaksananya berbagai program pemerintah. Pengurangan masa jabatan mengandung harapan agar penyalahgunaan jabatan kepala desa bisa dicegah.

Hal serupa berlaku juga pada UndangUndang No. 32/2004 tentang Pemerintahan Daerah, yang mengatur bahwa masa jabatan kepala desa adalah 6 tahun (boleh dipilih kembali 1 kali masa jabatan selanjutnya). Meskipun demikian, apabila UU No. 22/1999 dan UU No. 32/2004 dibandingkan, tentu ditemukan adanya perbedaan. Perbedaan yang dimaksud yaitu adanya selisih satu tahun, di mana masa jabatan kepala desa dalam undang-undang kedua lebih besar ketimbang undang-undang yang pertama. Penetapan masa jabatan 5 tahun pada UU No. 32/2004 barangkali menjadikan kinerja kepala desa kurang optimal. Oleh karena itulah, produk legislasi berikutnya merombaknya menjadi 6 tahun.

Berdasarkan catatan historis, peraturan perundang-undangan yang terbit belakangan genap membatasi masa jabatan kepala desa. Langkah ini dilakukan dalam rangka mencegah seseorang menjabat kepala desa terlampau lama dan memberikan kesempatan bagi orang lain untuk memimpin desa. Sistem demokrasi menggariskan persamaan hak bagi semua warga, termasuk dalam kontestasi pemimpin lokal. Jabatan kepala desa tidak dikhususkan bagi orang-orang dengan kekuatan materi atau berstatus sosial tinggi. Selama memenuhi persyaratannya, siapa pun berpeluang untuk mengabdikan diri selaku pemimpin desa. Semua lapisan masyarakat berhak turut berpartisipasi menyumbang tenaga, pikiran, serta waktunya dalam upaya menjadikan desa lebih maju dan berkembang.

Perpanjangan masa jabatan kepala desa pada umumnya diberlakukan satu kali. UU No. 22/1999 dan UU No. 32/2004 menggariskan ketentuan demikian. Ini berarti, setelah masa kerjanya habis, kepala desa boleh menambahnya satu periode. Apabila pada saat lengser kepala desa kembali mengikuti kontestasi dan terpilih, maka ia dituntut bersedia meletakkan jabatan ketika masanya berakhir. Ketentuan inilah yang tidak dijumpai dalam perundang-undangan tentang desa terbaru. UU No. 6/2014 menyebutkan bahwa kepala desa yang telah menjalankan tugasnya selama satu kali periode (6 tahun) boleh terpilih kembali 2 (dua) kali masa jabatan selanjutnya.

Dalam UU No. 6/2014 disebutkan bahwa seseorang boleh menduduki kursi kepala desa selama tiga periode, baik secara berturut-turut maupun tidak berturut-turut. Dengan demikian, apabila undang-undang yang terbit pasca reformasi tersebut menggariskan bahwa masa jabatan kepala desa adalah 6 tahun, maka seseorang boleh mempertahankan posisinya selaku pemimpin lokal selama 18 tahun. Muatan dalam UU No. 6/2014 tidak jauh berbeda dengan apa yang telah diatur dalam UU No. 5/1979 bahwa masa jabatan kepala desa selama-lamanya adalah 16 tahun atau dua periode, di mana setiap periodenya berjangka waktu 8 tahun. Bila merujuk pada Undang-Undang No. 23 tahun 2014 tentang Pemerintahan Daerah, maka UU No. 6/2014 mengandung kejanggalan. UU No. 23/2014 menyebutkan bahwa masa jabatan kepala daerah adalah 5 (lima) tahun serta boleh terpilih kembali dalam jabatan yang sama hanya untuk satu kali masa jabatan.

Padahal, jika memuat filosofi dan prinsip yang sama, maka masa jabatan kepala daerah dalam UU No. 23/2014 dan masa jabatan kepala desa dalam UU No. $6 / 2014$ juga semestinya disamakan. Apabila UU No. 23/2014 menggariskan bahwa masa jabatan kepala daerah adalah 5 tahun (boleh dipilih kembali 1 kali masa jabatan 
selanjutnya), maka UU No. 6/2014 menetapkan hal serupa bagi kepala desa. Anehnya, ketentuan tersebut ternyata tidak ditemukan dalam UU No. 6/2014. Ini berarti, logika berpikir yang digunakan dalam kedua undang-undang tersebut berlainan. Dari segi esensinya, jabatan kepala daerah tentu berbeda dengan jabatan kepala desa. Sehingga, masa jabatan kedua macam pemimpin tersebut juga dibedakan.

Perbedaan ketentuan mengenai masa jabatan pemimpin lokal (kepala daerah dan kepala desa) dalam UU No. 23/2014 dan UU No. 6/2014 menunjukkan bahwa filosofi dan paradigma berpikir kedua undang-undang tersebut juga berlainan. Dengan filosofi dan paradigma berpikir masing-masing, setiap produk legislasi memiliki "point of view", misi, serta kepentingan yang ingin diraih. Bagaimanapun, undang-undang adalah produk politik. Dengan demikian, meski misalnya dua produk perundang-undangan mengatur objek hukum yang sama, boleh jadi terdapat perbedaan ketentuan di dalamnya. Ini merupakan hal yang lumrah manakala apa yang ingin dibidik keduanya memang berlainan. Filosofi dan paradigma menentukan materi, muatan, dan isi (konten) sebuah undang-undang.

Meskipun demikian, ketentuan di atas perlu disikapi dengan kritis. Bagaimanapun, lamanya seseorang menduduki jabatan rentan berakibat pada munculnya penyimpangan. Ketika jabatan seseorang melebihi batas sewajarnya, tentu ia dikhawatirkan menyalahgunakan posisi dan wewenangnya. Apabila menduduki kursi kepala desa selama 18 tahun, maka bisa jadi ia akan mengelola pemerintahan desa secara serampangan. Dalam konteks inilah, demokrasi prosedural dan substansial mengalami pengeroposan. Aspirasi warga benar-benar dinihilkan, adapun hasrat elite lokal untuk berkuasa justru memperoleh dukungan. Imbasnya, beragam akses politik, sosial, serta ekonomi dikuasai oleh kepala desa beserta orang-orang yang dekat dengannya.

Konfigurasi politik di taraf lokal kerap diwarnai oleh perilaku nepotisme. Cita-cita komunal terkalahkan oleh hasrat individual, sedangkan kepentingan publik dikesampingkan demi tercapainya kepentingan individu. Atas dasar pemikiran inilah, masa jabatan yang terlampau panjang dikhawatirkan dapat melahirkan kembali 'raja-raja kecil' di desa. Di samping menumbuhkan hasrat mengejar keuntungankeuntungan berjangka pendek, lamanya kepala desa menjabat juga membuat peluang warga desa lain yang ingin berkontribusi membangun desa semakin kecil. Ditambah lagi, dengan diperbolehkannya kepala desa mempertahankan posisinya selama tiga periode, kaderisasi kepemimpinan di level lokal bakal mengalami hambatan serius.

Terbitnya UU No. 6/2014 berpotensi mengundang konflik atau problematika politik dan sosial di level desa, antara lain memanasnya perebutan kursi kepala desa sebagaimana pemilihan kepala daerah (pilkada). Boleh jadi proses-proses politik kian marak dengan menjamurnya money politic. Peran pemimpin tertinggi di komunitas berbasis ruang tersebut cukup strategis, dikarenakan pada dasarnya perebutan ditujukan bukan sekadar pada jabatan kepala desa, melainkan nilai nominal dan kepastian Anggaran Dana Desa (ADD). Ditambah lagi, peluang masa jabatan sampai tiga periode (18 tahun, setiap periode 6 tahun) mendorong figur-figur potensial di desa memperebutkan jabatan kepala desa berikut perangkatnya. Sehingga, kecenderungan demikian pada taraf tertentu bisa mengganggu harmoni sosial di wilayah perdesaan (Ida, 2014).

Padahal, salah satu tujuan penerbitan UU No. 6/2014 adalah memposisikan kepala desa sesuai kapasitasnya. Sebagaimana diketahui, pada masa Orde Baru, kepala desa adalah tokoh sentral dan dominan yang menguasai kehidupan desa. Itulah mengapa, sumber ekonomi dan penghidupan masyarakat kerap berada di tangannya. Ia leluasa mengendalikan bermacam kepentingan sekaligus meredam suara kritis warga. Bila ditelusuri secara mendalam, ketetapan mengenai panjangnya masa jabatan kepala desa dalam UU No. 6/2014 
mempunyai keterkaitan dengan semangat para penyusunnya. Undang-undang tersebut menyimpan hasrat menegaskan desa sebagai bagian dari pemerintahan daerah, meletakkan posisi desa di hadapan supra desa, sekaligus menguatkan kekuasaan negara terhadap desa.

Untuk lebih jelasnya, berikut disajikan perbandingan masa jabatan kepala desa sejak diterbitkannya UU No. 22/1999, UU No. 32/2004, hingga UU No. 6/2014:

Tabel 1.

Perbandingan Masa Jabatan Kepala Desa dalam UU

\begin{tabular}{|c|c|c|}
\hline $\begin{array}{l}\text { Payung } \\
\text { Hukum }\end{array}$ & $\begin{array}{c}\text { Masa Jabatan } \\
\text { Kepala Desa }\end{array}$ & Keterangan \\
\hline $\begin{array}{l}\text { UU No. } \\
22 / 1999\end{array}$ & $\begin{array}{c}5 \text { tahun (boleh } \\
\text { dipilih kembali } \\
1 \text { kali masa } \\
\text { jabatan } \\
\text { selanjutnya) }\end{array}$ & $\begin{array}{c}\text { Masa kerja } \\
\text { maksimal } \\
\text { dua periode } \\
\text { atau } 10 \\
\text { tahun }\end{array}$ \\
\hline $\begin{array}{l}\text { UU No. } \\
\text { 32/2004 }\end{array}$ & $\begin{array}{l}6 \text { tahun (boleh } \\
\text { dipilih kembali } 1 \\
\text { kali masa jabatan } \\
\text { selanjutnya) }\end{array}$ & $\begin{array}{c}\text { Masa kerja } \\
\text { maksimal } \\
\text { dua periode } \\
\text { atau } 12 \\
\text { tahun }\end{array}$ \\
\hline $\begin{array}{l}\text { UU No. } \\
6 / 2014\end{array}$ & $\begin{array}{c}6 \text { tahun (boleh } \\
\text { dipilih kembali } 2 \\
\text { kali masa jabatan } \\
\text { selanjutnya) }\end{array}$ & $\begin{array}{c}\text { Masa kerja } \\
\text { maksimal } \\
\text { dua periode } \\
\text { atau } 18 \\
\text { tahun }\end{array}$ \\
\hline
\end{tabular}

Uraian di atas menunjukkan bahwa pembatasan kekuasaan melalui masa jabatan kepala desa pada peraturan perundangundangan tentang desa terbaru cenderung merosot ketimbang peraturan perundangundangan tentang desa sebelumnya. Melalui masa jabatan yang ditetapkan dalam UU No. 6/2014, kekuasaan kepala desa bukannya dilemahkan, tetapi justru diperkuat. Aturan legal menjadikan seseorang berpeluang menjabat selaku pemimpin lokal selama tiga periode; Norma yang tak dijumpai pada UU No. 22/1999 dan UU No. 32/2004 yang menetapkan masa kerja kepala desa maksimal dua periode.

Dalam hal memberikan peluang kepala desa untuk mempertahankan kedudukannya melalui masa jabatan, UU No. 6/2014 dinilai mempunyai porsi paling besar, disusul UU No. 32/2004, baru kemudian UU No. 22/1999. Begitu pula sebaliknya. Dalam hal memangkas peluang kepala desa untuk mempertahankan kedudukannya melalui masa jabatan, UU No. 22/1999 dianggap memiliki porsi paling besar, disusul UU No. 32/2004, baru kemudian UU No. 6/2014. Dalam hal memberikan atau memangkas peluang kepala desa untuk mempertahankan kedudukannya melalui masa jabatan, UU No. 32/2004 mempunyai porsi yang paling seimbang daripada UU No. 6/2014 dan UU No. 22/1999.

\section{Pembatasan Kekuasaan melalui Masa Jabatan Kepala Desa dalam Peraturan Perundang-undangan Menurut Tinjauan Konstitusi}

Konstitusi digunakan oleh penulis untuk menggali lebih jauh merosotnya pembatasan kekuasaan melalui masa jabatan kepala desa dalam peraturan perundang-undangan. Dalam kaitannya dengan hal ini, penetapan masa jabatan dalam UU No. 22/1999, UU No. 32/2004, dan UU No. 6/2014 perlu ditarik dalam hierarki peraturan perundangundangan. Namun demikian, penulis tidak perlu kembali menyinggung ketiga undangundang yang dimaksud. Karena pembatasan kekuasaan melalui masa jabatan kepala desa mengalami kemerosotan terutama pada peraturan perundang-undangan tentang desa terbaru, maka pembahasan ini lebih difokuskan pada UU No. 6/2014.

Berdasarkan pemikiran di atas, norma yang diatur dalam UU No. 6/2014 harus dikembalikan kepada konstitusi. Sehingga, Undang-Undang Dasar Negara Republik Indonesia Tahun 1945 (UUD NRI 1945) mesti menjadi rujukan atau pedoman atas ditetapkannya suatu norma dalam undangundang tersebut. Dalam konteks ini, bila penetapan masa jabatan kepala desa cocok dengan apa yang terkandung dalam UUD 
NRI 1945, maka norma tersebut dinilai konstitusional. Begitu pula sebaliknya. Jika penetapan masa jabatan kepala desa kurang sesuai atau bahkan bertolak belakang dengan muatan dalam UUD NRI 1945, maka norma tersebut dianggap inkonstitusional.

Sebagaimana dikemukakan oleh Friedrich, konstitusionalisme didefinisikan "an insti- tutionalised system of effective, regularised restraints upon governmental action" (suatu sistem yang terlembagakan, menyangkut pembatasan yang efektif dan teratur terhadap tindakan-tindakan pemerintahan). Dalam pengertian ini, apa yang dianggap terpenting dalam setiap konstitusi yaitu pengaturan tentang pengawasan atau pembatasan terhadap kekuasaan pemerintahan (Asshiddiqie, 2010).

Peraturan bahwa seseorang boleh menduduki kursi kepala desa selama tiga periode (18 tahun) dalam perspektif konstitusi tentu mengingkari konsensus masyarakat dalam negara modern. Terlalu lamanya seseorang menjabat kepala desa menutup kemungkinan orang lain untuk mengambil peluang yang sama. Bagaimanapun, hak setiap warga negara untuk diperlakukan secara sederajat perlu memperoleh perlindungan. Padahal, mengutip Abrar Saleng, pengaturan dan pembatasan kekuasaan harus termanifestasi dalam peraturan yang mengutamakan keadilan (Saleng, 2004).

Pada zaman sekarang, konstitusi dianggap konsep yang niscaya bagi setiap negara modern. Basis pokok konstitusi yaitu kesepakatan umum atau persetujuan (consensus) mayoritas rakyat tentang bangunan yang diidealkan dalam negara. Warga masyarakat politik membutuhkan organisasi negara supaya kepentingan mereka terlindungi atau dipromosikan melalui pembentukan dan penggunaan mekanismenya (Asshiddiqie, 2010).

Diperbolehkannya seseorang menjabat kepala desa selama tiga periode (18 tahun) bertolak belakang dengan cita-cita hukum dan konstitusi. Bila ditinjau secara seksama, norma tersebut mengesampingkan adanya pembatasan kekuasaan. Padahal, normanorma yang diatur dalam setiap peraturan perundang-undangan, termasuk UU No. 6/2014, seharusnya memuat pembatasan kekuasaan. Apalagi konstitusi telah menegaskan, negara Indonesia adalah Negara Hukum (Rechtsstaat), bukan Negara Kekuasaan (Machtsstaat). Merujuk Dahlan Thaib, istilah Rechtsstaat dalam sistem pemerintahan Indonesia menurut Friedman mengandung arti pembatasan kekuasaan oleh hukum (Thaib, 2003).

Konsep kedaulatan dewasa ini harus dipahami sebagai konsep kekuasaan tertinggi yang dapat dibagi dan dibatasi. Betapa pun tingginya, pembatasan kekuasaan harus bisa dilihat dalam sifat internalnya yang umumnya diatur dalam konstitusi. Pada masa kini, pembatasan yang dimaksud biasanya terkait dengan ide konstitusionalisme negara modern. Artinya, di tangan siapa pun kekuasaan tertinggi atau kedaulatan berada, hukum dan konstitusi sebagai produk kesepakatan bersama para pemilik kedaulatan tersebut selalu melakukan pembatasan (Asshiddiqie, 2010).

Kekuasaan yang melekat pada desa mempunyai kemiripan dengan kekuasaan yang ada pada negara. Meski kekuasaan pertama bertaraf lokal, sementara kekuasaan terakhir berlevel nasional, tetapi keduanya memuat logika berpikir serupa. Oleh karena itu, pemimpin lokal senantiasa dibebani dengan tanggung jawab, tuntutan, serta kewajiban layaknya pemimpin nasional. Kepentingan publik harus diutamakan melebihi kepentingan penguasa. Dengan demikian, kekuasaan desa mesti dijauhkan dari gejala-gejala kesewenangan penguasa, sebagaimana kekuasaan negara.

Prinsip-prinsip pemisahan atau pembagian kekuasaan bermaksud membatasi kekuasaan negara dari kemungkinan munculnya penindasan dan tindakan sewenang-wenang penguasa. Pengaturan dan pembatasan kekuasaan merupakan ciri konstitusionalisme sekaligus tugas utama konstitusi. Dengan demikian, kemungkinan terjadinya kesewenang- 
wenangan kekuasaan dapat diperkecil. Jika tidak dikendalikan dan dibatasi dengan prosedur konstitusional, hukum besi kekuasaan bisa saja berubah menjadi sumber malapetaka. Moral kekuasaan tidak boleh diserahkan hanya pada niat atau sifat-sifat pemegangnya. Betapa pun baiknya seseorang, kekuasaan tetap senantiasa diatur dan dibatasi, supaya kebaikan orang tidak tertelan oleh hukum besi kekuasaan (Asshiddiqie, 2010).

Optimalisasi pemerintahan desa antara lain dilakukan dengan melakukan pergantian kepemimpinan secara berkala. Di samping menghindarkan munculnya penguasa tunggal yang mendominasi beragam bidang kehidupan warga, langkah ini juga ditempuh untuk menghadirkan generasi bagu pemegang estafet kepemimpinan lokal. Di sinilah urgensi dan relevansi adanya regenerasi. Bagaimanapun, kontestasi di level lokal bermaksud menjaring siapa saja yang menyimpan kompetensi untuk mengembangkan desa sekaligus melanjutkan berlangsungnya kepemimpinan lokal.

Diperkenankannya kepala desa menduduki jabatan selama tiga periode (18 tahun) dalam UU No. 6/2014 terkesan melemahkan semangat konstitusi. Mengutip pendapat Retno Saraswati, Pasal 39 ayat (2) undang-undang ini menyebutkan bahwa kepala desa dapat menjabat paling banyak tiga kali masa jabatan secara berturut-turut atau tidak berturut-turut. Sementara arah politik hukum dalam konstitusi menggariskan bahwa masa jabatan Presiden, Wakil Presiden, anggota DPR, anggota DPD, serta lembaga-lembaga lainnya dibatasi dengan dua kali masa jabatan atau dua periode. Dengan demikian, pengaturan bahwa kepala desa bisa menjalankan tugasnya selama tiga kali masa jabatan tidak konsisten dengan arah politik hukum mengenai masa jabatan dalam konstitusi. Secara teoretis, kekuasaan yang terlalu lama cenderung akan rusak atau berpotensi menjadi korupsi, sebagaimana pernyataan Lord Acton "Power trends to corrupt, and absolute power corrupt absolutely" (kekuasaan itu cenderung korup, dan kekuasaan yang absolut cenderung korup secara absolut) (Saraswati, 2014).

Padahal, setiap norma dalam peraturan perundang-undangan selayaknya mendukung dan menguatkan konstitusi. Di sinilah pentingnya kesesuaian antara muatan dalam UUD NRI 1945 dan berbagai aturan legal di bawahnya. Jabatan kepala desa sebaiknya merujuk pada periodisasi jabatan politik yang telah ditetapkan dalam UUD NRI 1945. Sehingga, muncul kesepahaman arah politik hukum berbagai jenjang atau tingkatan dalam hierarki perundangundangan. Apabila terjadi kontradiksi, maka bisa dipastikan ketentuan dalam ayat atau pasal mengingkari nilai-nilai yang diusung oleh konstitusi.

Berdasarkan supremasi konstitusi, tidak boleh terjadi pertentangan antara peraturan perundang-undangan di bawah konstitusi dengan konstitusi. Oleh karena itu, adanya mekanisme untuk menilai konstitusionalitas dari suatu undang-undang (constitutionality of legislation) merupakan keharusan (Salman, 2017).

Selain paham Negara Hukum sebagaimana disebutkan di atas, kajian tentang pembatasan kekuasaan juga terkait erat dengan paham kedaulatan rakyat. Ini berarti, pembahasan masa jabatan kepala desa selama tiga periode (18 tahun) yang ditetapkan melalui UU No. 6/2014 menuntut pemahaman mendalam mengenai konsep negara hukum dan kedaulatan rakyat. Dalam upaya menilai apakah norma tersebut konstitusional atau tidak, keduanya perlu dipahami secara serius.

Negara Indonesia menganut paham kedaulatan rakyat (democratie). Pada hakikatnya, rakyat merupakan pemilik kekuasaan tertinggi di negara Indonesia. Dengan demikian, kekuasaan tersebut mesti disadari berasal dari rakyat, oleh rakyat, dan untuk rakyat. Bahkan, hendaklah kekuasaan diselenggarakan bersama dengan rakyat. Dalam sistem konstitusional berdasarkan Undang-Undang Dasar, implementasi kedaulatan rakyat disalurkan dan diselenggarakan menurut prosedur 
konstitusional yang digariskan dalam hukum dan konstitusi (constitutional democracy) (Asshiddiqie, 2010).

Norma dalam UU No. 6/2014 yang menggariskan masa jabatan kepala desa selama tiga periode (18 tahun) menunjukkan minimnya ikhtiar membatasi kekuasaan di tingkat lokal. Apabila ditinjau secara seksama, terpilihnya seseorang menjadi kepala desa selama tiga periode (18 tahun) di suatu desa bukanlah suatu jaminan atau kepastian. Bagaimanapun, tidak seorang pun mampu menjamin bahwa jabatan pemimpin lokal tersebut bisa dipertahankan selama jangka waktu tertentu. Akan tetapi, usaha menjauhkan kepala desa dari kekuasaan terlalu besar bahkan absolut harus senantiasa ditempuh. Sebab, penempatan suatu jabatan publik dalam tataran proporsional merupakan sebagian tuntutan konstitusi. Itulah mengapa, saat menjalankan tugas dan fungsinya, kepala desa mesti berada dalam masa kerja yang wajar.

Minimnya upaya membatasi kekuasaan dapat memunculkan dominasi kepala desa di hadapan warga. Berjalannya pemerintahan desa sangat bergantung pada preferensi, kehendak, serta kemauan kepala desa. Dalam kondisi inilah, kepala desa rentan bertindak di luar kapasitasnya. Peran dan fungsi yang semestinya dilimpahkan kepada orang lain pada akhirnya justru diambil alih oleh kepala desa. Perasaan superior di dalam dirinya menjadikan kepala desa menihilkan kemampuan orang lain sekaligus meletakkan dirinya selaku aktor lokal paling utama.

Padahal, salah satu prinsip pokok negara hukum (Rechtsstaat) pada zaman sekarang yaitu pembatasan kekuasaan. Pembatasan kekuasaan negara dan organorgan negara ditempuh dengan menerapkan prinsip pembagian kekuasaan secara vertikal atau pemisahan kekuasaan secara horizontal. Kekuasaan harus selalu dibatasi dengan cara memisahkan kekuasaan ke dalam cabangcabang yang bersifat 'checks and balances' dalam posisi sederajat, saling mengimbangi dan mengendalikan satu sama lain. Pembatasan kekuasaan juga diberlakukan dengan membagi kekuasaan ke dalam beberapa organ yang tersusun secara vertikal. Dengan demikian, kekuasaan tidak tersentralisasi dan terkonsentrasi dalam satu organ atau satu tangan yang memungkinkan terjadinya kesewenang-wenangan (Asshiddiqie, 2010).

Realisasi pembatasan kekuasaan kepala desa menandai terwujudnya kehidupan demokratis di level akar rumput (grassroots). Sebagaimana pemerintahan pusat, pemerintahan desa juga mesti dijauhkan dari penguasa sentralistis dan otoriter. Demokrasi meniscayakan bahwa beragam bentuk kekuasaan, terutama yang menyangkut hajat hidup orang banyak, harus dibatasi. Kekuasaan yang dijalankan terlalu lama akan melahirkan otoritarianisme, di mana fungsi pemerintahan terkonsentrasi pada peran pemimpin. Bagaimanapun, pembatasan kekuasaan merupakan salah satu ciri demokrasi.

Pembatasan kekuasaan kepala desa melalui masa jabatan berkenaan dengan psikologi manusia. Faktor-faktor yang bersifat psikis turut mempengaruhi cara seseorang menjalankan tugas dan kewajibannya sebagai pemimpin. Dalam taraf tertentu, hubungan yang terjalin antara pemimpin dengan pihak yang dipimpin kerap diwarnai dengan berbagai perasaan. Itulah mengapa, baik kepala desa maupun warganya merasakan kejenuhan apabila masa kepemimpinan berlangsung terlampau lama. Dalam perjalanannya, kondisi semacam ini tentu lebih banyak mendatangkan kerugian daripada manfaat dan kemaslahatan. Kepemimpinan di level lokal yang selayaknya melahirkan inovasi, progresivitas, serta kebijakan strategis justru menyebabkan kemunduran.

Ramlan Surbakti memandang bahwa jabatan bersifat relatif tetap, sedangkan pemegang jabatan bersifat tidak tetap. Dalam keadaan normal, umur jabatan suatu institusi lazimnya lebih panjang dibanding umur manusia. Di samping pendeknya umur manusia, sifat sementara dari masa jabatan penjabat juga disebabkan oleh terbatasnya kemampuan dan kearifan manusia. Keterbatasan ini merupakan akibat 
kecenderungan manusia untuk terjebak rutinitas bila menjabat cukup lama serta kebosanannya melaksanakan pekerjaan yang sama dalam waktu panjang. Akhirnya, selain prakarsa dan kreativitasnya merosot lantaran miskin tantangan, ia juga semakin tidak sabar melihat bawahan dalam melaksanakan fungsinya sehingga cenderung menyerobot tugas dan kewenangan bawahannya (Surbakti, 1998).

Atas dasar itulah, baik secara langsung maupun tidak, masa jabatan seorang penjabat, terutama kepala pemerintahan, semestinya dibatasi. Kecuali kemampuan dan kearifan manusia yang cukup terbatas, terdapat alasan-alasan lain mengapa suksesi harus dilakukan. Semakin lama seseorang menjabat, semakin ia memperlakukan jabatan sebagai milik pribadi. Sehingga, setiap kritik terhadap jabatan dianggap kritik terhadap pribadinya. Begitu pula sebaliknya, kritik atas pribadinya dilihat sebagai kritik atas jabatan. Konsekuensi dari situasi demikian yaitu penyalahgunaan jabatan demi kepentingan pribadi dan keluarga serta pengesampingan kepentingan publik. Keadaan seperti inilah yang melahirkan fenomena korupsi, kolusi, koncoisme dan nepotisme $(\mathrm{K} 3 \mathrm{~N})$ pada masa rezim Orde Baru (Surbakti, 1998).

Pergantian pemimpin merupakan kebutuhan vital. Cukup panjangnya masa kerja kepala desa mengesankan terbatasnya potensi dan sumber daya manusia di wilayah pedalaman. Lamanya seseorang menduduki kursi kepala desa menunjukkan bahwa seolah dirinya saja yang dibekali kemampuan untuk membangun, mengembangkan, serta memajukan desa. Dalam logika tradisional, hal ini barangkali bisa dibenarkan. Apalagi, menurut catatan sejarah, figur potensial di desa dahulu kala memang sangat terbatas. Di samping itu, dipertahankannya seseorang menjadi pemimpin komunitas berbasis ruang tersebut akibat mengakarnya feodalisme dalam kehidupan masyarakat perdesaan. Sehingga, penokohan terhadap individu merupakan keniscayaan yang diwariskan lintas generasi.
Akan tetapi, kini, pemikiran demikian perlu dikoreksi. Peralihan waktu dan perubahan kondisi melahirkan generasi yang cerdas dan kompetitif. Atas dasar inilah, kepemimpinan lokal sejatinya bukan dikuasai oleh klan atau kelompok masyarakat tertentu, melainkan dapat diakses oleh semua orang. Berbeda dengan masa kuno yang membolehkan pengangkatan pemimpin berdasarkan keturunan dan wahyu, zaman modern menuntut adanya rivalitas dalam meraih setiap jabatan publik. Persyaratan yang berhubungan dengan aspek-aspek magis dan mitologis tidak lagi relevan. Kewibawaan, kearifan, kesaktian, serta nilai-nilai bercorak tradisional lainnya mulai tergantikan dengan prestasi dan ukuran rasional.

Alasan lain yang tidak kalah penting dari pelaksanaan suksesi yaitu kecenderungan kekuasaan untuk berkembang biak. Bila seseorang menjabat terlalu lama, tanpa batas waktu, tanpa kontrol rakyat secara politik dan kontrol hukum dari lembaga peradilan, maka kewenangan formal ini rentan digunakan untuk memperoleh sarana kekuasaan lainnya, semisal sarana koersi dan sarana ekonomi yang selanjutnya dipakai untuk mempertahankan kewenangannya. Semakin lama bertahan dalam jabatan, semakin besar kemungkinan seseorang untuk mengembangbiakkan kekuasaan. Semakin besar pula kemungkinan penyalahgunaan kekuasaan yang merugikan masyarakat serta merusak tatanan negara sebagaimana diatur dalam konstitusi (Surbakti, 1998).

\section{Simpulan}

Berdasarkan pendekatan undangundang, pembatasan kekuasaan melalui masa jabatan kepala desa mengalami kemerosotan terutama pada UU No. 6/2014. Adapun berdasarkan pendekatan konstitusi, norma yang menyebutkan diperkenankannya seseorang menjabat sebagai kepala desa selama tiga periode (18 tahun) dalam UU No. 6/2014 bertolak belakang dengan arah politik hukum dalam UUD NRI Tahun 45. 
Dengan demikian, norma tersebut dinilai inkonstitusional.

Konstitusi menghendaki bahwa setiap penduduk berhak menduduki kursi kepala desa. Siapa saja yang terdaftar selaku warga negara Indonesia dipersilakan mencalonkan diri sebagai pemimpin komunitas masyarakat hukum tersebut. Konstitusi menjunjung tinggi prinsip, nilai, serta etos demokrasi. Berlainan dengan karakter oligarki, di mana segelintir orang mengantongi keistimewaan dan prioritas dalam lingkaran kekuasaan, demokrasi mengajarkan bahwa rakyat turut memegang kendali kekuasaan. Dalam pemerintahan yang bersifat demokratis, kepentingan publik senantiasa diutamakan melebihi kepentingan individu.

Pemikiran di atas menghindarkan adanya usaha seseorang melakukan koptasi atas kekuasaan lokal. Dalam taraf tertentu, sentralisasi diakibatkan oleh adanya dominasi dalam kehidupan masyarakat. Bagaimanapun, peluang menjadi pemimpin desa terbuka bagi siapa saja yang mampu memenuhi persyaratan dalam peraturan perundang-undangan. Jabatan kepala desa tidak boleh hanya dimiliki oleh segelintir orang. Pembatasan masa jabatan juga memuat pemahaman bahwa fungsi kepala desa bisa lebih maksimal dan proporsional apabila dijalankan dalam jangka waktu yang terbatas. Dalam konteks ini, masa jabatan kepala desa maksimal dua periode lebih rasional dan demokratis ketimbang tiga periode.

\section{DAFTAR PUSTAKA}

Adhuri, D S. (2002). Antara Desa dan Marga: Pemilihan Struktur pada Perilaku Elit Lokal di Kabupaten Lahat, Sumatera Selatan. Jurnal Antropologi Indonesia, (No. 68), p.6.

Antlov, H. (2003). Negara dalam Desa: Patronase Kepemimpinan Lokal. Cetakan Kedua. Yogyakarta: Lapera Pustaka Utama.
Asshiddiqie, J. (2010). Konstitusi dan Konstitusionalisme. Jakarta: Sinar Grafika.

Cahyono, H. (2005). Konflik Elite Politik di Pedesaan: Relasi antara Badan Perwakilan Desa dan Pemerintah Desa. Jurnal Penelitian Politik, Vol. 2 (No. 1), p.73.

Fahmi, E (2002). Menata Ulang Tatanan Kehidupan Bersama: Peran Sistem Pengurusan. Wacana, Jurnal Ilmu Sosial Transformatif, Edisi X, pp.129130.

Ida, L. (2014, Januari 08). Undang-Undang Desa dan Tantangannya. Harian Kompas.

Juliantara, D (ed.). (2000). Arus Bawah Demokrasi: Otonomi dan Pemberdayaan Desa. Yogyakarta: Lapera Pustaka Utama.

Permana, Y S. (2010). Kontestasi AbanganSantri Pasca Orde Baru di Pedesaan Jawa. Jurnal Ilmu Sosial dan Ilmu Politik, Vol. 14 (No. 1), p.74.

Romli, L. (2007). Potret Otonomi Daerah. Yogyakarta: Pustaka Pelajar.

Sahdan, G (ed.). 2005. Transformasi Ekonomi-Politik Desa. Yogyakarta: APMD Press.

Salman, R. (2017). Pengujian UndangUndang oleh Mahkamah Konstitusi dalam Perspektif Konstitusionalisme dan Demokrasi. Universitas Airlangga.

Saleng, A. (2004). Penegakan Hukum dalam Era Reformasi. Jurnal Ius Quia Iustum, Vol. 11 (No. 25), p.149.

Saraswati, R. (2014). Arah Politik Hukum Pengaturan Desa ke Depan (Ius Constituendum). Jurnal MasalahMasalah Hukum, Vol 43 (No. 3), p.316.

Thaib, D. (2003). Menuju Parlemen Bikameral (Studi Konstitusional Perubahan Ketiga UUD 1945). Jurnal Ius Quia Iustum, Vol. 10 (No. 23), p.91. 
Surbakti, R. (1998). Naskah Pidato

Pengukuhan Guru Besar. Universitas

Airlangga. 